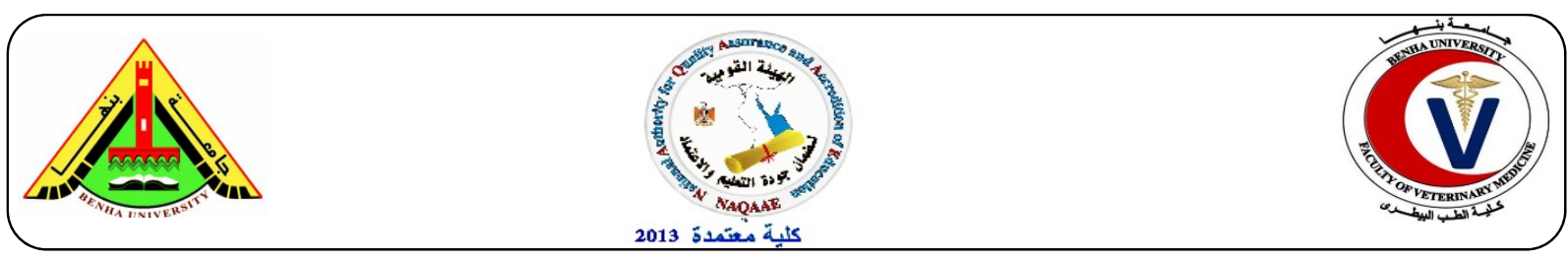

\title{
Preparation and field evaluation of live attenuated sheep pox vaccine for protection of calves against lumpy skin disease
}

\author{
Heba A. Khafagy ${ }^{\text {b }}$, Mohamed G. Abdelwahab a, Abdelmoneim M. Mustafa a , Mohamed A. \\ Saad $^{\text {b }}$ \\ ${ }^{a}$ department of Animal Medicine, Faculty of Veterinary Medicine, Benha, Egypt, ${ }^{b}$ Central Laboratory for Evaluation of \\ Veterinary Biologics, Abbassia, Cairo, Egypt.
}

\section{A B S T R A C T}

In this research Romanian Sheep pox virus was identified and confirmed by using PCR, Live attenuated Romanian Sheep pox vaccine (RSPV) was prepared and its titer on VERO cell was log $10^{2.5} \mathrm{TCID}_{50} /$ dose. It was sterile, safe and potent. We used eight susceptible calves 6-8 months old, five calves vaccinated with $0.5 \mathrm{ml}$ of prepared RSP vaccine intra dermally (I/D) in tail folds while three calves kept as control. Evaluation of both acquired humoral and cellular immunity by using lymphocyte proliferation assay, SNT, ELISA and Interferon Gamma Bioassay (IFN- $\gamma$ ). The result showed that lymphocyte proliferation began to increase till reach to its peak (1.629) at $10^{\text {th }}$ day then decrease after that, While Interferon gamma $(\mathrm{IFN}-\gamma)$ detected in $1^{\text {st }}$ day till $7^{\text {th }}$ day post vaccination then decreases after that. Results of SNT and ELISA revealed that Protective serum neutralizing antibody titer started at three weeks (1.5), (1.09) post vaccination then reach to its peak at $12^{\text {th }}$ weeks $(2.5),(1.85)$ respectively and persisted till 28 weeks. From this study we found that live attenuated RSP vaccine a good immunogenic response where it was induced a high level of antibody titer with prolonged duration of immunity and higher lymphocyte and interferon gamma levels, So It considered good vaccine to control Lumpy Skin Disease (LSD).

Keywords: PCR, VERO, RSPV, SNT, ELISA, IFN- ${ }_{\gamma}$, LSD.

(http://www.bvmj.bu.edu.eg)

(BVMJ-31(2): 1-7, 2016)

\section{INTRODUCTION}

The capri pox viruses cause the most severe pox diseases of animals. Epidemiologically the diseases of sheep pox, goat pox and lumpy skin disease differ, but all three viruses may be mechanically transmitted by biting insects, and control without vaccination is extremely difficult in endemic areas. Recently developed live attenuated vaccines provide good, virtually lifelong, protection, which is dependent on stimulating cell- mediated immunity (Buller et al., 2005; Carn, 1993). Lumpy skin disease was first reported in Africa. In May 1988, LSD was recognized clinically in the Suez Governorate of Egypt, where it was thought to have arrived at the local quarantine station with cattle imported from Africa (Somalia) (FAO, 2000; Gari et al., 2011). LSD is characterized by fever, nodules on the skin, lesions in the mouth, pharynx and respiratory tract, emaciation, enlargedlymph nodes, oedema of the skin, it also causes high morbidity rate reach $100 \%$ and sometimes death.The disease is more severe in cows at peak lactation and causes a sharp drop in milk yield,often leading to secondary bacterial mastitis. It also causes Temporary or permanent infertility may occur in cows and bulls (Desta Hamito, 2009; Tuppurainen and Oura, 2012). Vaccination is considered the best suitable way to control Lumpy Skin Disease, so this research aims to prepare live attenuated RSP vaccine and sterility, safety and potency of vaccine were evaluated. Evaluation of cell-mediated immune response by using lymphocyte proliferation assay and Interferon Gamma Bioassay $\left(\mathrm{IFN}_{-}-\mathrm{)}\right.$, while humoral immunity was evaluated by using SNT and ELISA. Result was provided that prepared vaccine gave good, lifelong protection which is dependent on stimulating humoral and cellular immunity.

\section{Material and Methods.}

\subsection{Calves:}

Ten susceptible calves 6-8 months old apparently health were tested to be free from 
antibody against sheep pox virus and examined clinically for persisted of experiment ( 28 weeks). two calves were used for safety test, while five calves were inoculated with $0.5 \mathrm{ml} / / \mathrm{D}$ in tail folds by prepared vaccine $\left(\log 10^{2.5} \mathrm{TCID}_{50}\right)$, and three of them kept as control.

\subsection{Virus:}

\section{Romanian Sheep pox virus (RSPV)}

It was supplied from Pox Department, Veterinary Serum and Vaccine Research Institute (VSVRI), Egypt. The virus was cultivated on Vero according to (Rizkallah, 1994; Singh and Rai, 1991). The strain was used for vaccine preparation and serological test (SNT, ELISA).

\subsection{Primers:}

Primers for sheep pox virus developed from the gene for viral fusion protien with the following sequences. Forward primer:

5'-TGTTGTACTTCGTCCTGTTTGAA-3' , Reverse primer:

5'-CGACGATGATGAAACCAATG -3' It was obtained from Jena Bioscience company, Germany.

\subsection{Titration of Romanian Sheep pox virus:}

Titration of RSPV on Vero cell according to (Rao and Malik, 1982).The titer of virus was expressed as $\log { }_{10} \mathrm{TCID}_{50} / \mathrm{ml}$ of the original inoculation using the formula of (Reed and Muench, 1938).

\subsection{Preparation of live attenuated Romanian Sheep pox vaccine:}

Live attenuated Romanian Sheep pox vaccine was prepared by mixing of stabilizer solution with the virus fluid of attenuated virus at the ratio $1: 1$ (v:v). Each $100 \mathrm{ml}$ vaccine mixed with $100 \mathrm{IU} / \mathrm{ml}$ penicillin and $100 \mu \mathrm{g} / \mathrm{ml}$ streptomycin sulfate according to (OIE, 2004).

\subsection{Titration of the prepared vaccine:}

Titration of prepared RSPV vaccine on Vero cell according to (Rao and Malik, 1982; Tiwari and Negi, 1995).

\subsection{Sterility test:}

The prepared vaccine was tested for its sterility and purity to be free from bacterial, fungal and mycoplasmal contamination according to (OIE, 2004).

\subsection{Safety of the prepared vaccine:}

The prepared vaccine was tested for its safety by inoculation of two calves intra dermally (I/D) with 20x of the field dose of RSP vaccine to check its safety as described by (Mahmoud et al., 1988).

\subsection{Vaccination of animals:}

Five calves were vaccinated intra dermally in the tail fold with $0.5 \mathrm{ml}$ of the prepared vaccine $\left(\log 10^{2.5} \mathrm{TCID}_{50}\right)$, while three calves were kept as control. Animals were observed daily for one month for clinical signs, including body temperature, swelling at the site of inoculation, or generalized skin lesions.as described by (Daoud et al., 1998; Wang and Jiang, 1988a).

\subsection{Evaluation of lymphocyte proliferation assay:}

Whole blood was collected 1, 3, 5, 7, 10, 14, 21 and 28 days post vaccination for estimation of the cellular immunity according to (Charles et al., 1978; Lucy, 1984), kits were purchased from Promokine, Catalog Number: PK-CR-20-3001000, Lot No.:743182, Germany.

\subsection{Detection of interferon gamma by using Sandwich ELISA:}

It measured quantitatively by using ELISA according to (Lin Fan et al., 2012). Kits were purchased from ID Vet, Catalog Number: IFNG2P-0912, Lot No 540, France.

\subsection{Serum sample:}

Serum samples were collected from vaccinated calves at the time of vaccination then weekly for 1 st month, each two weeks at $2^{\text {nd }}$ month then monthly till the end of the experiment and it was stored at $-20^{\circ} \mathrm{c}$ until examined by SNT and ELISA according to (Martin et al., 1975; OIE, 2010).

\section{RESULTS}

The size of PCR product for Romanian Sheep pox virus by using the specific primer of fusion protein gene was $(\sim 412 \mathrm{pb})$ as shown in (Figure.1). Titration of sheep pox virus "Romanian strain" on VERO cell showed that Cytopathic effect (CPE) from the vaccinal seed virus began to appear two days post inoculation and reach the maximum (70$80 \%$ ) on the 5 th day, and its titer reached $\log 10^{6.0}$ $\log 10 \mathrm{TCID}_{50} / \mathrm{ml}$. Titration of prepared vaccine on Vero cell revealed that titer was $10^{2.5} \mathrm{TCID}_{50} / \mathrm{ml}$. Sterility test and Safety test showed that prepared vaccine was free from aerobic, anaerobic bacteria, fungi and mycoplasma. The vaccine was safe where body temperature remained within the normal temperature range $\left(38.3-39.1 \mathrm{C}^{\circ}\right)$ for 15 days post vaccination with accepted local reaction at site of inoculation. 
Clinical examination of vaccinated calves showed that slight increase in body temperature $\left(0.4^{\circ} \mathrm{c}\right)$ in average 3 days post vaccination and also showed mild skin lesions appeared as redness and hotness at the inoculation site 5 to 7 days post vaccination. These reactions diminished within one week then dis appeared Later. Cell mediated immune response of vaccinated calves began to increase till reach to Its peak at $10^{\text {th }}$ day (1.629) then decreased until the end of the experiment at $28^{\text {th }}$ day post vaccination as clarified in (Table.1). Interferon gamma $\left(\mathrm{IFN}_{-}\right)$of vaccinated calves with prepared vaccine showed that (IFN- $\gamma$ ) level in the first day was $(22 \%)$ and at seven day was $(16 \%)$ post vaccination then decrease after that as clarified in (Table.2). Neutralizing antibody titer in calves vaccinated with prepared RSP vaccine by SNT revealed that antibody titer reached protective level (1.5) at third week post vaccination and increased gradually till reach (2.5) at 12 weeks post vaccination then reached to (1.6) at 28 weeks from vaccination and began to decrease than protective level. As showed in (Table.3). Immune response in calves vaccinated with prepared RSP vaccine by ELISA showed that antibody level reached (1.09) at third week post vaccination and increased gradually till reach (1.85) at 12 weeks post vaccination then reached to (1.02) at 28 weeks from vaccination then began to decrease than protective level. The result was showed in (Table.4)

Figure (1): PCR product of sheep pox virus

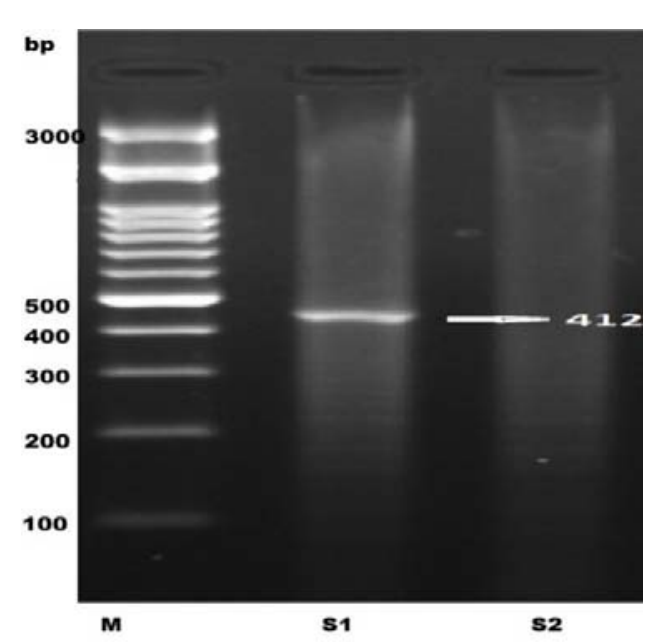

Figure (1) Specific at the correct expected size of the fusion protein gene $(\sim 412 \mathrm{pb})$, Lane M: High molecular weight nucleic acid marker, Lane 1: Sheep pox virus and Lane 2: control negative.

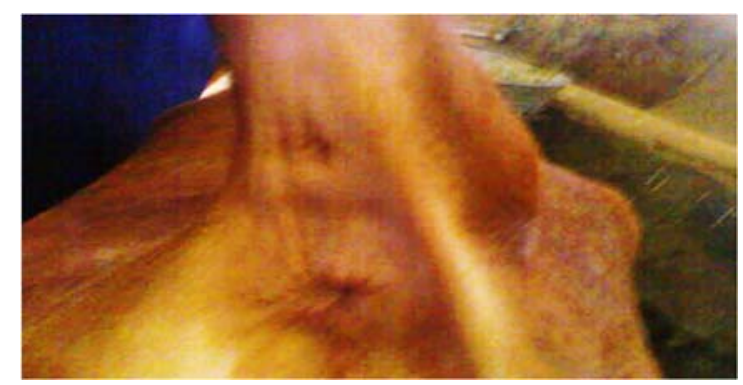

Photo 1: Post vaccinal reaction in calves vaccinated with RSP vaccine.

Table (1): Cell mediated immune response of calves vaccinated with RSP vaccines and control non vaccinated calves.

\begin{tabular}{ccccccccccc}
\hline & \multicolumn{8}{c}{ Days post vaccination } \\
\cline { 2 - 10 } Calves No. & 0 & 1 & 3 & 5 & 7 & 10 & 14 & 21 & 28 \\
Calf 1 & 0.075 & 0.191 & 0.270 & 0.362 & 0.680 & 1.125 & 1.000 & 0.784 & 0.375 \\
Calf 2 & 0.079 & 0.218 & 0.282 & 0.440 & 0.714 & 1.200 & 1.055 & 0.692 & 0.267 \\
Calf 3 & 0.090 & 0.245 & 0.386 & 0.511 & 0.800 & 2.250 & 1.048 & 0.717 & 0.320 \\
Calf 4 & 0.083 & 0.205 & 0.289 & 0.490 & 0.845 & 1.890 & 1.053 & 0.694 & 0.388 \\
Calf 5 & 0.078 & 0.238 & 0.299 & 0.547 & 0.796 & 1.678 & 1.065 & 0.643 & 0.297 \\
Average & 0.081 & 0.219 & 0.305 & 0.470 & 0.767 & 1.629 & 1.044 & 0.706 & 0.329 \\
Control & 0.077 & 0.082 & 0.085 & 0.087 & 0.087 & 0.088 & 0.090 & 0.080 & 0.077 \\
\hline
\end{tabular}

0 day: before vaccination (on the time of vaccination), OD: optical density 
Heba Khafagy et al. (2016). BVMJ-31(2): 1-7

Table (2): Cell mediated immune response of calves vaccinated with RSP vaccine by Interferon gamma assay $(\mathrm{IFN}-\gamma)$.

\begin{tabular}{lccccccccc}
\hline $\begin{array}{l}\text { calf no. } \\
\text { and status }\end{array}$ & \multicolumn{10}{c}{ Days post vaccination } \\
\cline { 2 - 9 } Calf 1 & 0 & 1 & 3 & 5 & 7 & 10 & 14 & 21 & 28 \\
Status & $-\mathrm{ve}$ & $22 \%$ & $18 \%$ & $16 \%$ & $10 \%$ & $7 \%$ & $7 \%$ & $6 \%$ & $4 \%$ \\
Calf 2 & $6 \%$ & $20 \%$ & $17 \%$ & $15 \%$ & $11 \%$ & $9 \%$ & $7 \%$ & $5 \%$ & $3 \%$ \\
Status & $-\mathrm{ve}$ & $+\mathrm{ve}$ & $+\mathrm{ve}$ & $+\mathrm{ve}$ & $-\mathrm{ve}$ & $-\mathrm{ve}$ & $-\mathrm{ve}$ & $-\mathrm{ve}$ & $-\mathrm{ve}$ \\
Calf 3 & $8 \%$ & $21 \%$ & $19 \%$ & $16 \%$ & $14 \%$ & $12 \%$ & $9 \%$ & $8 \%$ & $6 \%$ \\
Status & $-\mathrm{ve}$ & $+\mathrm{ve}$ & $+\mathrm{ve}$ & $+\mathrm{ve}$ & $-\mathrm{ve}$ & $-\mathrm{ve}$ & $-\mathrm{ve}$ & $-\mathrm{ve}$ & $-\mathrm{ve}$ \\
Calf 4 & $7 \%$ & $18 \%$ & $18 \%$ & $16 \%$ & $13 \%$ & $10 \%$ & $9 \%$ & $6 \%$ & $3 \%$ \\
Status & $-\mathrm{ve}$ & $+\mathrm{ve}$ & $+\mathrm{ve}$ & $+\mathrm{ve}$ & $-\mathrm{ve}$ & $-\mathrm{ve}$ & $-\mathrm{ve}$ & $-\mathrm{ve}$ & $-\mathrm{ve}$ \\
Calf 5 & $9 \%$ & $23 \%$ & $19 \%$ & $17 \%$ & $14 \%$ & $11 \%$ & $8 \%$ & $7 \%$ & $5 \%$ \\
Status & $-\mathrm{ve}$ & $+\mathrm{ve}$ & $+\mathrm{ve}$ & $+\mathrm{ve}$ & $-\mathrm{ve}$ & $-\mathrm{ve}$ & $-\mathrm{ve}$ & $-\mathrm{ve}$ & $-\mathrm{ve}$ \\
Control & $0 \%$ & $0 \%$ & $0 \%$ & $0 \%$ & $0 \%$ & $0 \%$ & $0 \%$ & $0 \%$ & $0 \%$ \\
Status & $-\mathrm{ve}$ & $-\mathrm{ve}$ & $-\mathrm{ve}$ & $-\mathrm{ve}$ & $-\mathrm{ve}$ & $-\mathrm{ve}$ & $-\mathrm{ve}$ & $-\mathrm{ve}$ & $-\mathrm{ve}$ \\
\hline
\end{tabular}

Positive: $\quad \mathrm{S} / \mathrm{P} \%$ more than 15\%. Negative: $\quad \mathrm{S} / \mathrm{P} \%$ less than $15 \%, \mathrm{~S} / \mathrm{p}:$ mean sample positive

\section{DISCUSSION}

Vaccination has been considered to be the cheapest and suitable means in control of Capripox diseases control as it stimulate both humoral and cell mediated immune response (Deshmukh and Gujar, 1992).

In this study we evaluated the prepared live attenuated Romanian sheep pox vaccine and its immune response to protect calves against LSD.

By using PCR we identified and confirmed the Romanian sheep pox virus (RSP) and it showed unique band of the size ( $\sim 412 \mathrm{bp})$ for fusion protein as recorded by (El-Bagoury et al., 2009) who reported that specific PCR product at the correct expected size of the fusion protein gene (412bp) for Capri pox viruses.

The prepared live attenuated vaccine was tested for sterility and the results proved that the vaccine was negative to any contaminating agents as bacteria, moulds and fungi. This result mentioned by (Code of federal Regulation, 2005; Wassel et al., 1996), who reported that the final product should be free from bacteria, fungi and mycoplasma.

Safety of the prepared vaccine was studied in calves (as 20x of vaccine dose) and satisfactory results of safety with no rise in body temperature and no clinical signs. This result recorded previously by (Code of federal Regulation, 2005; Mahmoud et al., 1988; OIE, 2012) who reported that the final product should gave good satisfactory result of safety with no rise in body temperature of vaccinated animals and it remained healthy for period of 15 days post vaccination which indicated that the vaccine was safe.

Clinical examination of calves vaccinated with prepared RSP vaccine showed only mild local reaction appeared in the form of redness and mild swelling as shown by (Carn, 1993; Coetzer, 2004; OIE, 1992; Woods, 1988). The recorded clinical signs were also in agreed with (Diallo and Viljoen j.g., 2007), who found that the clinical signs caused by different Capripox viruses were very variable, depending not only individual host susceptibility but also on the virus strain, slight reaction and slight rise in temperature could be explained that the vaccine stimulated the immune system in the susceptible animal.

There is evidence that cell mediated immune response plays an important role against Capri pox beside humeral immunity (Bachh et al., 1997). The increased lymphocyte proliferation due to specific RSP antigens stimulation agreed with the reports of (Ahmed et al., 2007).

Lymphocyte MTT proliferation assay was chosen for estimation of cell mediated immune response (Charles et al., 1978; Lucy, 1984). Cell mediated immune response in vaccinated calves with prepared RSP vaccine ranged in between $0.081-1.629$ all over the experiment. The result recorded previously by previous reports (Amal, 1995; Amira, 1997; Kaaden et al., 1992; Olfat et al., 2002), who reported the increase of lymphocyte activity by the 3rd day post vaccination and reached its peak on the 10th day then decreased till the $30^{\text {th }}$ day post vaccination. 
Table (3): Mean of neutralization index in vaccinated calves with RSP vaccine.

\begin{tabular}{|c|c|c|c|c|c|c|c|c|c|c|c|c|c|c|c|c|c|}
\hline \multirow{3}{*}{$\begin{array}{l}\text { NO. of } \\
\text { Animals }\end{array}$} & \multicolumn{17}{|c|}{ SNT titer* } \\
\hline & \multicolumn{17}{|c|}{ Weeks post vaccination } \\
\hline & 0 & 1 & 2 & 3 & 4 & 6 & 8 & 12 & 16 & 20 & 24 & 28 & 32 & 36 & 40 & 44 & 48 \\
\hline Calf 1 & 0.3 & 0.6 & 0.6 & 0.6 & 0.9 & 1.8 & 2.1 & 2.4 & 2.1 & 1.8 & 1.8 & 0.9 & 0.6 & 0.6 & 0.6 & 0.3 & 0.3 \\
\hline Calf 2 & 0.3 & 0.6 & 0.9 & 0.9 & 1.8 & 1.8 & 2.1 & 2.4 & 2.1 & 1.8 & 1.8 & 0.9 & 0.9 & 0.9 & 0.6 & 0.6 & 0.3 \\
\hline Calf 3 & 0.6 & 0.6 & 0.9 & 1.8 & 1.8 & 2.4 & 2.4 & 2.7 & 2.4 & 2.2 & 1.8 & 1.8 & 0.9 & 0.9 & 0.6 & 0.6 & 0.3 \\
\hline Calf 4 & 0.3 & 0.6 & 1.8 & 2.1 & 2.1 & 2.4 & 2.4 & 2.7 & 2.4 & 2.2 & 2.1 & 2.1 & 1.8 & 0.9 & 0.6 & 0.6 & 0.3 \\
\hline Calf 5 & 0.36 & 0.6 & 1.8 & 2.1 & 2.4 & 2.4 & 2.4 & 2.4 & 2.1 & 2.1 & 1.8 & 1.8 & 1.8 & 1.2 & 0.6 & 0.6 & 0.3 \\
\hline Mean & 0.3 & 0.6 & 1.2 & 1.5 & 1.8 & 2.1 & 2.3 & 2.5 & 2.3 & 2.1 & 1.8 & 1.6 & 1.2 & 0.9 & 0.6 & 0.5 & 0.3 \\
\hline Control & 0.23 & 0.21 & 0.23 & 0.3 & 0.36 & 0.36 & 0.3 & 0.36 & 0.3 & 0.3 & 0.2 & 0.3 & 0.36 & 0.33 & 0.19 & 0.12 & 0.10 \\
\hline
\end{tabular}

* Serum neutralizing antibody titer expressed as $\log 10 . N B$ : Neutralizing Index $(\mathrm{NI}) \geq 1.5$ considered protective mean against capri pox viruses.

Table (4): Immune response in calves vaccinated with prepared RSP vaccine by ELISA.

\begin{tabular}{ccccccccccccccccccc}
\hline $\begin{array}{c}\text { NO. of } \\
\text { animals }\end{array}$ & \multicolumn{110}{c}{ Weeks post vaccination } \\
\cline { 2 - 4 } & 0 & 1 & 2 & 3 & 4 & 6 & 8 & 12 & 16 & 20 & 24 & 28 & 32 & 36 & 40 & 44 & 48 \\
\hline Calf 1 & 0.72 & 0.89 & 0.98 & 1.09 & 1.18 & 1.52 & 1.71 & 1.84 & 1.67 & 1.46 & 1.21 & 1.03 & 0.64 & 0.46 & 0.23 & 0.17 & 0.05 \\
Calf 2 & 0.65 & 0.78 & 0.99 & 1.09 & 1.23 & 1.55 & 1.74 & 1.85 & 1.66 & 1.45 & 1.22 & 1.02 & 0.63 & 0.44 & 0.27 & 0.19 & 0.09 \\
Calf 3 & 0.76 & 0.86 & 0.89 & 1.08 & 1.20 & 1.54 & 1.73 & 1.84 & 1.66 & 1.44 & 1.25 & 1.01 & 0.68 & 0.43 & 0.25 & 0.12 & 0.06 \\
Calf 4 & 0.66 & 0.75 & 0.96 & 1.10 & 1.28 & 1.56 & 1.73 & 1.86 & 1.68 & 1.46 & 1.21 & 1.03 & 0.67 & 0.41 & 0.20 & 0.11 & 0.09 \\
Calf 5 & 0.59 & 0.77 & 0.95 & 1.07 & 1.26 & 1.53 & 1.69 & 1.84 & 1.67 & 1.45 & 1.22 & 1.02 & 0.66 & 0.36 & 0.29 & 0.17 & 0.08 \\
Mean & 0.68 & 0.81 & 0.95 & 1.09 & 1.23 & 1.54 & 1.72 & 1.85 & 1.67 & 1.45 & 1.22 & 1.02 & 0.66 & 0.42 & 0.25 & 0.15 & 0.07 \\
Control & 0.33 & 0.29 & 0.26 & 0.25 & 0.23 & 0.21 & 0.19 & 0.12 & 0.11 & 0.09 & 0.08 & 0.06 & 0.06 & 0.05 & 0.05 & 0.04 & 0.03 \\
\hline
\end{tabular}

${ }^{+}$Ve: equal or more than $1 .{ }^{-} \mathrm{Ve}$ : less than 1 
Gamma interferon (IFN- $\gamma$ ) is an important cytokine in the host defense against infection by viral and microbial pathogens (Strichman and Samuel, 2001), and it activates pathways that can directly inhibit virus. Interferon-gamma release assays are new immunologic diagnostic tools for detection of a T-cell immune response to the antigens. Calves vaccinated with live attenuated Romanian sheep pox vaccine showed ELISA antibody in the first day (22\%) till five days (16\%) post vaccination then decrease after that. That result was found with (Charles et al., 1978; Nfon et al., 2012) who detected that experimentally infected calves produced serum IFN- $\gamma$, IL-12 and other pro inflammatory cytokines but not IFN- $\alpha$. Despite the lack of IFN- $\alpha$, innate immunity via the IL-12 to IFN- $\gamma$ circuit possibly contributed to early protection against LSD since neutralizing antibodies were detected after viremia had cleared.

Humoral Immune response depending mainly on the antibody titers in sera of vaccinated calves by using SNT and ELISA. Vaccinated calves reached protective level (1.5) at third week post vaccination and increased gradually till reach (2.5) at 12 weeks post vaccination then reached to (1.6) at 28 weeks from vaccination then began to decrease than protective level. This result recorded by Cotral (1978); OIE (2010) that reported neutralizing Index $(\mathrm{NI}) \geq 1.5$ considered protective mean against capri pox viruses. These results were found by Agag et al. ( 1992) where they mentioned that serum neutralizing antibodies develop on the $2^{\text {nd }}$ day and a significant rise of antibody titer was detected from the $21^{\text {th }}$ to $42^{\text {th }}$ day post inoculation. Neutralization is very specific for almost all viruses (Davies and Otema, 1981; Fassi-Fehri et al., 1984; OIE, 2000) employed SNT to study the antigenic relationship between SPV, GPV and LSD, to confirm the disease or to assess the post vaccinal immune status. The obtained results were in contrast with Kitching et al. (1989) who reported that the immune status of a previously infected or vaccinated animal cannot be related to serum level of neutralizing antibody, they concluded that, although the virus neutralization test is the most specific serological test, but because immunity to capri pox infection is predominantly cell mediated, the test is not sufficient.

ELISA was considered one of recommended serological tests used for diagnosis of capri pox viruses (OIE, 2004). calves vaccinated with prepared RSP reached protective level of ELISA antibody (1.09) at third week post vaccination and increased gradually till reach (1.85) at 12 weeks post vaccination then reached to (1.02) at 28 weeks from vaccination then began to decrease than protective level. This result was recorded by Suri et al. (1984); Wassel et al. (1996) who concluded that caperi pox vaccines is the most effective immunogenic available and provide both cellular and humeral immunity.

From above study we concluded that live attenuated RSP vaccine give good immunogenic, inducing a high level of antibody titer with prolonged duration of immunity, higher lymphocyte and interferon $\gamma$ level so it considered suitable vaccine to control the disease in the field.

\section{REFERENCES}

Agag, B.I., Mousa, S., Hassan, H.B., Saber, M.S., El-Deghidy, N.S., Abdel Aziz, A.M., 1992. Clinical serological and biochemical studies on LSD. Lumpy Skin Veterinary Sciences 33, 58-66.

Ahmed, A.M., Mukhtar, M.M., El Hussein, A.m., Tageldin, A.M., Fadol, M.A., 2007. Immune response of sheep vaccinated with Capripox vaccine. Vet. Res. 1, 12-16.

Amal, A.F. 1995. Studies on cell mediated immunity of sheep pox virus vaccineM.V. Sc, Cairo Univ.

Amira, A.E. 1997. Evaluation of lumpy skin disease virus vaccine using cell-mediated immuneMCSC, Cairo Uni.

Bachh, A.S., Ram, G.C., Hopkins, J., Bansal, M.P., 1997. Observations on cellular response in experimentally sheep-pox-infected lambs. Indian J Anim Sci 67, 263-266.

Buller, R., Arif, B., Black, D., Dumbell, K., Esposito, J., Lefkowitz, E., McFadden, G., Moss, B., Mercer AA, Moyer, R., Skinner, M., 2005. Virus Taxonomy. Elsevier Academic Press, , San Diego.

Carn, V.M., 1993. Control of capripoxvirus infections. Vaccine 11, 1275-1279.

Charles, R., Catpenter, A.B., Henry, R., Bose, J.R., 1978. Suppressionof the mitogen-stimulated blastogenic response during reticuloendotheliosis virus induced tumorigenesis. J. Immunol. 120 1313-1320.

Code of federal Regulation, 2005. Animal and animal products. Published by the office of the federalRegister National Archives and Recor Administration. 16, 101-107.

Coetzer, J.A.W., 2004. Lumpy skin disease. Oxford University press, inf. Dis. of livestock.

Cotral, J.A.W., 1978. Lumpy skin disease. Oxford University press, Southern Africa.

Daoud, A.M., Michael, A., Soad, M.S., Samir, S.S., Aboul-Soud, E.A., 1998. Production of lumpy skin vaccine in Egypt. Fac. Vet. Med., Zagazig, pp. 117-124. 
Davies, F.G., Otema, C., 1981. Relationships of capripox viruses found in Kenya with two Middle Eastern strains and some orthopox viruses. Research in veterinary science 31 , 253-255.

Deshmukh, V.V., Gujar, M.B., 1992. Study of cell mediated immune response in kids vaccinated and infected against goat-pox virus. Livestock Adviser 17, 7-10.

Desta Hamito, E.D., 2009. Chief of Party, ESGPIP SHEEP AND GOAT POX: Causes, prevention and treatment,. TECHNICAL BULLETIN.

Diallo, A., Viljoen J.G., 2007. Genus Capripox virus. Birkhäuser Verlag Basel/Switzerland, 167-181.

El-Bagoury, G.E., El-Habbaa, A.S., Abdel-Nour, E.T., 2009. Isolation and Molecular Characterization of Lumpy Skin Disease Virus from Kalubia Governorate. Benha Vet. Med. J. 20.

FAO, 2000. A growing problem in Africa and the Near East. FAO Corporate, Document Repository.

Fassi-Fehri, M., El-Harrak, M., Johnson, O., Abbadi, M., El- Idrissi, A.H., 1984. Experimental study of post vaccinal immunity to sheep pox Vaccines. Annales de Recherches Vétérinaires 15, 59-64.

Gari, G., Bonnet, P., Roger, F., Waret-Szkuta, A., 2011. Epidemiological aspects and financial impact of lumpy skin disease in Ethiopia. Prev Vet Med 102, 274-283.

Kaaden, O.R., Walz, A., Czerny, C.P., Wernery, U., 1992. Progress in the development of camel pox vaccine, In: International Camel Conf, Dubai.

Kitching, R.P., Bhat, P.P., Black, D.N., 1989. The characterization of African strains of capripoxvirus. Epidemiol Infect 102, 335343.

Lucy, F.L., 1984. Proliferative response of chicken $\mathrm{B}$ and $\mathrm{T}$ lymphocytes to mitogens. Chemical regulation of immunity in vetrenary medicin 15, 44-52.

Mahmoud, M.A., Zahida, H., Afzal, S., 1988. Preparation of live sheep pox tissue culture vaccine. Pakistan Vet. J. 8, 56-61.

Martin, W.B., Erhan, M., Onar, B., 1975. Studies on sheep pox vaccine serum-virus neutralization test. Pendik Vet. Kont. ve Arastirm Institusu Dergisi 8 26-47.

Nfon, C.K., Marszal, P., Zhang, S.Z., Weingartl, H.M., 2012. Innate Immune Response to Rift Valley Fever Virus in Goats. Plos Neglect Trop D 6.
OIE, 1992. Manual of recommended diagnostic techniques and requirements for biological products. OIE, Rue de Prony 1, 1-5.

OIE, 2000. Lumpy skin Disease In Manual of standards chapter 200-217.

OIE, 2004. Manual of Diagnostic tests and vaccines for terrestrial animals. OIE Part 2, $1-17$.

OIE, 2010. Lumpy skin disease. InManual of Diagnostic Tests and Vaccines for Terrestrial Animals. OIE, Paris 1-13.

OIE, 2012. Safety and efficacy of capripox viruses.

Olfat, E.N., Samir, S.S., Manal, A., Soad, M.S., Daoud, A.M., 2002. Studies on cell mediated immune response of Goats vaccinated with Goat pox vaccine. Fac. Vet. Med., Zagazig, pp. 139-151.

Rao, T.V.S., Malik, B.S., 1982. Behaviour of sheep pox, goat pox and Contagious pustular dermatitis viruses in cell culture. Ind, J. Compara. Microbial Immunal and Infectious. Dis. 3, 26-33.

Reed, L.J., Muench, H., 1938. Simple method for estimating 50 percent end point. Amer. J. Hyg. 27, 493 - 497.

Rizkallah, S.S. 1994. Further studies on sheep pox disease in Egypt. PhD, Cairo University, Egypt.

Singh, M.P., Rai, A., 1991. Adaptation and growth of sheep pox virus in Vero cell culture Indian Veterinary Medical Journal 15, 245-250.

Strichman, R., Samuel, C.E., 2001. The role of gamma interferon in antimicrobial immunity Curr. Opin. Microbiol. 4, 251-259.

Suri, B.T., Mallick, B.B., Jhihgran , C., 1984. Detection of caperipox virus antibody by ELISA from field. Ind. J. An. Sci. 54, 261262.

Tiwari, A.K., Negi, B.S., 1995. Neutralization ability precipitinogens of goat. Ind. J. Compar. Microbiol. Immunal. and Infe. Dis. 16, 64-65.

Tuppurainen, E.S.M., Oura, C.A.L., 2012. lumpy skin disease: an emerging threat toEurope, the Middle East and Asia. Transbound. emerg. Dis. 59, 40-48.

Wang, S.H., Jiang, H.X., 1988a. Vaccination of sheep against sheep pox with an attenuated goat pox vaccine. Chinese Journal of Veterinary Medicine 14

Wassel, M.S., AboulSoaud, S., Girgis, S., Hussein, A.Z., Eman, E., 1996. Trail for preparation and evaluation of accompanied vaccine for capripox viruses in Egypt Assuit Vet. Med. J. 35 .

Woods, J.A., 1988. Lumpy skin disease--a review. Trop Anim Health Prod 20, 11-17. 